\title{
Response of Coffee Berry Borer (Hypothenemus hampaei) to Alcohol-Based Attractants on Coffee Crops in Banjarnegara, Indonesia
}

\author{
Rostaman $^{1^{*}}$, Budi Prakoso ${ }^{1}$ \\ ${ }^{1}$ Agrotechnology Department, Faculty of Agriculture, Jenderal Soedirman University \\ Jalan Dr. Suparno Purwokerto Indonesia \\ *Corresponding author. Email: rostamanos@yahoo.com
}

\begin{abstract}
Coffee berry borer (CBB) or Hypothenemus hampei Ferrari is a major insect pest on coffee crops in Indonesia. This pest could be controlled by using attractants that are placed in insect traps. The aim of this study was to examine the number of trapped CBB in alcohol-based attractants that were placed in the bottle traps. The experiment was conducted on coffee crops in polyculture system, during fruiting season (April-July 2019). Completely randomized design was used in this experiment. Three formulas of attractant used were methanol + ethanol mixture 1:1 (A1), methanol + ethanol mixture 3:1 (A2), and commercial product (A3). The attractants were placed in traps. The traps were laid randomly at poles or branches ca. $160 \mathrm{~cm}$ in height and $2.0 \times 2.0$ metre apart. Result showed that the number of trapped CBB in traps that were filled with commercial formula (A3) was higher than the traps that were filled with other attractants (A1 and A2 formula). The number of trapped $\mathrm{CBB}$ was higher in traps that were placed near plants than the traps that were placed far from plants.
\end{abstract}

Keywords: Hypothenemus hampei, $C B B$, coffee, attractant, bottle trap

\section{INTRODUCTION}

Coffee is the principal agricultural product for millions of small farmers in Indonesia. Its production contributes greatly to national economic development [1]. However, its production is threatened by the coffee berry borer (CBB) Hypothenemus hampei Ferrari. CBB is one of the most important insect pest of coffee crops in Indonesia [2]. The pest does not attack other crops [3]. It causes loss as much as $22-73 \%$ in Indonesia [4] and in other countries it could even reach $90-100 \%$ [5].

Farmers control the insect pests using various measures. The most popular measure is sanitation. Farmers pick up infested coffee berries that fell to the ground or still attached on twigs [2] Controlling the CBB using insecticides is not recommended due to its ineffectiveness [6] and the hazards to human health [3]. Kairomone or attractant is recommended for controlling the pest [7]. Kairomone is a substance emitted by plants that attracts CBB. Methanol and ethanol mixture is usually used as attractant for monitoring and mass trapping CBB [4, 7-9].

Based on coffee history, coffee and H. hampei in Indonesia came from Africa. The CBB lives in coffee crops for a long time. It changes insect behaviour, especially in response to chemicals that are emitted by plants, including attractants (alcohol compounds). The aim of this study was to examine the response of CBB to alcohol-based attractants that were placed in insect traps.

\subsection{Materials and Methods}

The experiment was conducted on coffee crops in polyculture system, during fruiting season (April-June 2019). Light intensity was ca 830 lux (range 329-1881 lux). Completely randomized design was used in this experiment. Three formulas of attractant were used, which are methanol-ethanol mixture 1:1 (A1), methanol-ethanol mixture 3:1 (A2), and a commercial product (Hypotan ${ }^{\circledR}$ ) (A3). Methanol and ethanol were produced by Brataco and Hypotan was produced by ICCRI (Indonesia Coffee and Cacao Research Institute). The formula A1 and A2 (30 $\mathrm{mL}$ ) were loaded in small cylindrical containers. The containers were hanged in bottle traps $(600 \mathrm{ml})$. The bottle traps were placed randomly at poles or coffee branches ca. $160 \mathrm{~cm}$ in height and $2.0 \times 2.0 \mathrm{~m}$ apart (Figure 1). The spacing of crops varies between 2-3 m. Number of traps was 16 units for each treatment. The distance of traps to crops was $20-120 \mathrm{~cm}$. The attractants were replaced every month. Number of insects trapped was recorded every week.

\subsection{Our Contribution}

This paper presents some new formula of attractant (methanol and ethanol mixture) that replaces commercial product. Also, it was found that the appropriate distance of traps to crops was less than $20 \mathrm{~cm}$. 


\subsection{Paper Structure}

The rest of the paper is organized as follows. Section 2 introduces the experiment result and discussion, while the last session presents conclusion of the paper and direction for the future research.

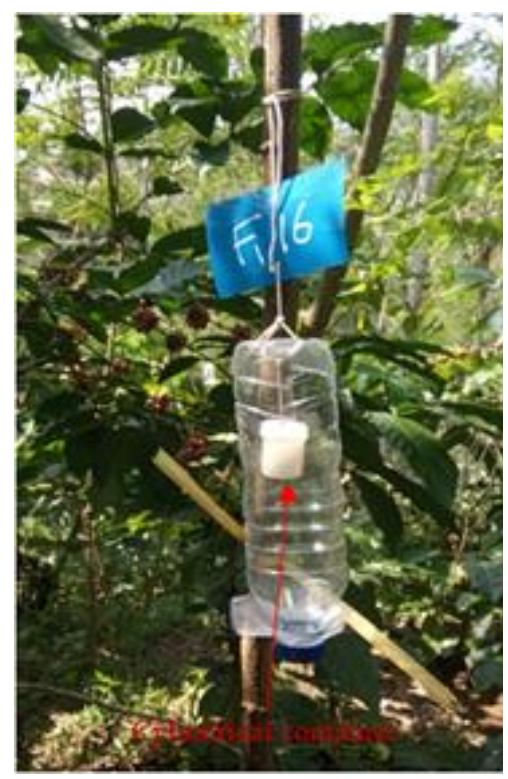

Figure 1 Bottle trap for catching CBB

\section{RESULTS AND DISCUSSION}

\subsection{Response of Coffee Berry Borer on Alcohol-based Attractants}

The coffee berry borer (CBB) responded to all alcoholbased attractants on coffee crops in Banjarnegara, Indonesia. The number of trapped CBB in bottle traps that were filled with commercial attractant (A3) was higher than in others (Table 1).

Table 1 Number of trapped coffee berry borer in 2 months

\begin{tabular}{|l|c|c|c|}
\hline \multirow{2}{*}{ Parameters } & \multicolumn{3}{|c|}{ Attractant* } \\
\cline { 2 - 4 } & A1 & A2 & A3 \\
\hline Mean & 6.38 & 5.88 & 14.63 \\
\hline $\begin{array}{l}\text { Standard } \\
\text { deviation }\end{array}$ & 7.91 & 6.04 & 21.59 \\
\hline Max & 29.00 & 18.00 & 86.00 \\
\hline Min & 0.00 & 0.00 & 0.00 \\
\hline
\end{tabular}

* A1 = methanol-ethanol mixture $1: 1$

A2 = methanol-ethanol mixture 3:1

A3 = commercial product $($ Hypotan $®)$

\subsection{Number of Trapped Coffee Berry Borer in Fruiting Season}

The number of trapped CBB in all traps increased during observation period. This might be caused by fruit maturity. Number of insects in bottle traps that contain commercial attractants was higher than in others (Figure 2)

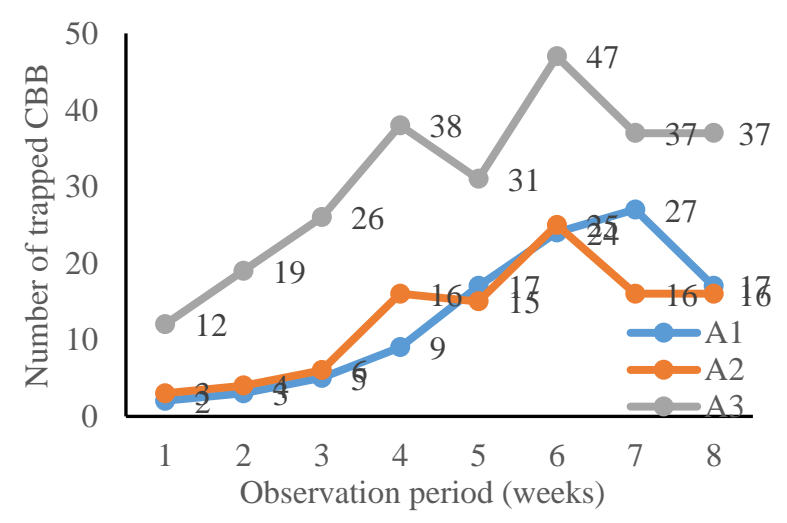

Figure 2 Number of trapped $\mathrm{CBB}$ in 2 months period

\subsection{Horizontal Dispersal of Insects}

Number of trapped insects was influenced by the distance of traps to coffee plants (Table 2). Number of insect was higher in traps placed nearest to the plants.

Table 2 Dispersal of trapped coffee berry borer based on the distance of traps to coffee plant

\begin{tabular}{|c|c|c|c|c|}
\hline No & $\begin{array}{c}\text { Distance } \\
\text { (cm) }\end{array}$ & $\begin{array}{c}\text { Number } \\
\text { of traps }\end{array}$ & $\begin{array}{c}\text { Number } \\
\text { of } \\
\text { insects }\end{array}$ & $\begin{array}{c}\text { Number } \\
\text { of } \\
\text { insects/ } \\
\text { traps }\end{array}$ \\
\hline 1 & $0-20$ & 15 & 238 & 15.9 \\
\hline 2 & $>20-40$ & 7 & 28 & 4.0 \\
\hline 3 & $>40-60$ & 7 & 44 & 6.3 \\
\hline 4 & $>60-80$ & 5 & 42 & 8.4 \\
\hline 5 & $>80-100$ & 5 & 27 & 5.4 \\
\hline 6 & $>100-120$ & 4 & 50 & 12.5 \\
\hline 7 & $>120$ & 5 & 24 & 4.8 \\
\hline
\end{tabular}

\subsection{Discussion}

This insect pest infested coffee berries at both young and mature stages. Infested young berries fall to the ground immediately. However, infested mature berries can also fall to the ground or stay attached to the plant. The insects develop in berries and emerge when they reached adulthood. Only the females can fly, whereas the males can not fly. The females fly to find host plant and males playrole 
for copulation. Reproductive females lay their eggs in the holes of berries that were bored before [2,3].

The insects are attracted to coffee berries due to the flavour or kairomone that is emitted by berries. Many chemical compounds are responsible for attracting the insect pest (H. hampei) [10-2]. These compounds consisted of R-3 ethyl-4-methyl pentanol, methylcyclohexne, nonane, and ethylbenzena. R-3 ethyl-4 methyl pentanol seems to be a powerful attractant from coffee berries. The insects responded to both methanol and ethanol mixture $(1: 1)$ and methanol and ethanol mixture (3:1). It depends on the area where coffee plants are cultivated. In Banjarnegara, the $\mathrm{CBB}$ responded to both mixture of methanol and ethanol.

The number of trapped CBB in alcohol-based attractant was lower than in the commercial attractant. However, alcohol mixture attractants were preferable due to the low cost and availability. The main problem in trapping insects was the dispenser that emits attractants. Dispensers of commercial product that were packed in sachets were able to emit compounds (attractants) slowly, whereas dispensers of alcohol mixture in cylindrical containers were not capable of slow release yet. Number of trapped CBB in all traps were still very low. This is because many insects flew upwind and out of traps. Therefore, it was needed to improve the traps by modifying the traps and adding detergent solution in the bottom of traps to trap the insects. Horizontal dispersal occurred in this experiment. Number of trapped CBB is also related to the distance of traps to plants (as the source of food for insects). Number of trapped CBB in traps that were placed near plants $(0-20 \mathrm{~cm})$ was higher than others traps (more than $20 \mathrm{~cm}$ ). This phenomenon also occured in vertical dispersal [5].

Number of trapped insects in traps that were placed at lower part $(50 \mathrm{~cm})$ was higher than others. These phenomenon occured due to be abundance of food (berries) on soil surface that serves as breeding sites. The insects will fly to the nearest attractant (or trap). This is in accordance with migration cost concept. Based on this concept, insects will fly to the nearest source of food conserve energy. The phenomenon of distance followed the mathematical model of the movement of $H$. hampei in space over time was $Y=$ $\alpha \beta^{X i}, \mathrm{Y}$ is the average number of insect and $x$ is the distance in meter [13]. If $x$ value is high then the number of insect is low and vice versa. The knowledge of insect dispersal is important to determine traps (and attractants) placement in monitoring and mass trapping program of $\mathrm{CBB}$.

\section{CONCLUSION}

We summarized that all the attractants could be used as tool for monitoring and or mass trapping coffee berry borer (H. hampei) on coffee crops in Indonesia. This measure can be done by all farmers because of the low cost and local availability.

\section{ACKNOWLEDGMENT}

The research was funded by BLU Unsoed Purwokerto, with contract number P/416/UN23/14/PN/2019. Thanks to rector Unsoed Purwokerto for funding. Also, thanks to coffee farmer group "Sido Makmur" and Mr. Muhammad Fahmi and Ms Dewi Yunani for technical assistance.

\section{REFERENCES}

[1] B. Sudjarmoko, Prospects of Indonesia coffe industrialization development, Sirinov. 1 (1) (2013) 99-110

[2] R. Harni, Samsudin, A. Widi, I. Gusti, S. Funny, Khaerati, T. Efi , H.M. Abdul, H.D. Arlia Dwi Hapsari, Teknologi Pengendalian Hama dan Penyakit Tanaman Kopi. Indonesian Agency for Agricultural Research and Development (IAARD) Press, 2015

[3] A. Damon, A review of the biology and control of the coffee berry borer, Hypothenemus hampei (Coleoptera: Scolytidae). B. Entomol. Res. 90 (2000) 453-465. DOI: https://doi.org/10.1017. S000748530000 0584

[4] S. Wiryadiputra, C. Cilas, J.P. Morin, Effectiveness of Brocap traps in controlling the coffee berry borer (Hypothenemus hampei) in Indonesia. International Conference on Coffee Science, Campinas Brazil, 2009, pp. 1405-1408

[5] D.H. Uemura-Lima, M.U Ventura, A.Y. Mikami, F.C. da Silva, L. Morales, Responses of coffee berry borer, Hypothenemus hampei Ferr (Coleoptera: Scolytidae), to vertical distribution of methanol: ethanol traps. Neotrop. Entomol. 39 (6) (2007) 930-933. DOI: https://doi.org/10.1590/ S1519-566X2010000600013

[6] E. Vega, F. Posada, F. Infantie, Coffee Insects: Ecology and control. Encylopedia of Pest Management, 2006, pp. 1-4

[7] B.P. Dufour, B. Frerot, Optimization of coffee borer, Hypothenemus hampei (Coleotera: Scolitidae), mass trapping with an attractant mixture. J. Appl. Entomol. 132 (7) (2008) 591-600. DOI: https://doi.org/10.1111/j.1439-0418.2008. 01291.x

[8] F.L. Fernandes, M.C Picanco, M.E.S. Fernandes, R.A.C Dangelo, F.F. Souza, R.N.C Guedes, A new and highly effective sampling plan using attractantbaited traps for the coffee berry borer (Hypothenemus hampei). J. Pest Sci. 88 (2015) 289-299. DOI: https://doi.org/10.1007/s10340014-0622-2 
[9] L.F. Aristizabal, M. Jimenez, A.E. Bustillo, H.I. Trujillo, S. P Arhturs, Monitoring coffee berry borer, Hypothenemus hampei, population with alcohol-baited funnel traps in coffee farm in Columbia. Fla. Entomol. 98 (1) (2015) 381-383. DOI: https://doi.org/10.1653/024.098.0165

[10] A.R. Ortiz, A.F. Ortiz, F.E. Vega, F. Posada, Volatile composition of coffee berries at different stages of ripeness and their possible attraction to the coffee berry borer Hypothenemus hampei (Coleoptera: Curculionidae). J. Agric. Food Chem. 5 (2004) 5914-5918. DOI: https://doi.org/10.1021/ jf049537c

[11] T.N. Njihia, J. Jaramillo, L. Murungi, D. Mwenda, B. Orindi, P. Hans-Michael, B. Torto, Spiroacetales in the colonization behaviour ot the coffee berry borer: A push pull system. PLosOne. 9 (11) (2014) 1- 12 e111316. DOI: https://doi.org/10.1371/ journal.pone. 0111316

[12] A.M. Castro, J. Tapias, A. Ortiz, P. Benavides, C.E. Gongora, Identification of attractant and repellent plants to coffee berry borer, Hypothenemus hampei. Entomol. Exp. Appl. 164 (2) (2017) 120130. DOI: https://doi.org/10.1111.eea.12604

[13] Z.N. Gil, P. Benavides, Og. D. Souza, F.E. Acevedo, E. Lima, Molecular markers as a method to evaluate the movement of Hypothenemus hampei (Ferrari). J. Insect. Sci. 15 (1) (2015) 1-8. DOI: https://doi.org/10.1093/jisesa/iev058 